\title{
EDXRF Analysis of Amazonian Burseraceae Oleoresins
}

\author{
André L. Rüdiger, ${ }^{a}$ Cláudia C. Silva ${ }^{*, b}$ and Valdir F. Veiga Junior ${ }^{a}$ \\ ${ }^{a}$ Departamento de Química, Instituto de Ciências Exatas, Universidade Federal do Amazonas, \\ 69077-040 Manaus-AM, Brazil \\ ${ }^{b}$ Coordenação de Engenharia Química, Escola Superior de Tecnologia, Universidade do Estado do Amazonas, \\ 69065-020 Manaus-AM, Brazil
}

\begin{abstract}
O breu exsudado das espécies de Burseraceae é amplamente utilizado tanto em cosméticos e perfumes quanto na medicina tradicional, para tratamento de diversos males. Amostras de breu de cinco espécies (Protium cf. apiculatum, P. cf. hebetatum, P. cf. heptaphyllum, P. tenuifolium e Trattinnikia peruviana), provenientes da Reserva Biológica Adolfo Ducke (Manaus-AM, Brasil), foram analisadas por FRXDE para determinação e quantificação dos elementos químicos com número atômico entre 11 e 92 . Em todas as amostras foram observados os elementos $\mathrm{S}, \mathrm{Cl}, \mathrm{Ca}$, $\mathrm{Fe}, \mathrm{Ti}, \mathrm{V}$ e Si, este último com as maiores concentrações (média de 13,1\%, m/m). Além destes, foram detectados $\mathrm{Na}, \mathrm{P}, \mathrm{Al}, \mathrm{Mg}, \mathrm{K}, \mathrm{Cr}$ e Mn. Excetuando-se o enxofre e o alumínio, a variação na concentração dos elementos presentes foi muito pequena $(\mathrm{CV}<13 \%)$, sugerindo um padrão de composição inorgânica para os breus desta região. Alguns elementos foram detectados em apenas algumas espécies, sugerindo capacidades diferenciadas de absorção.
\end{abstract}

The trees from the Burseraceae family exude a resin widely used for both cosmetics and perfumes and in folk medicine, for the treatment of many diseases. Samples of oleoresin from five species (Protium cf. apiculatum, $P$. cf. hebetatum, $P$. cf. heptaphyllum, $P$. tenuifolium and Trattinnikia peruviana) were collected in the Reserva Biológica Adolfo Ducke (Manaus-AM, Brazil) and analyzed through EDXRF for determination and quantification of the chemical elements with atomic numbers from 11 to 92 . In all samples the elements $\mathrm{S}, \mathrm{Cl}, \mathrm{Ca}, \mathrm{Fe}, \mathrm{Ti}, \mathrm{V}$ and $\mathrm{Si}$, were observed the last one having the highest concentrations $(13.1 \%, \mathrm{~m} / \mathrm{m})$. In addition to these elements, $\mathrm{Na}, \mathrm{P}, \mathrm{Al}, \mathrm{Mg}, \mathrm{K}, \mathrm{Cr}$ and $\mathrm{Mn}$ were also detected. Except for sulfur and aluminum, the variation of concentration of the elements present in the sample was very small $(\mathrm{CV}<13 \%$, $\mathrm{m} / \mathrm{m}$ ), suggesting a pattern of inorganic composition for the resins of this region. Some elements were detected in just some species, suggesting different capacities of absorption.

Keywords: Burseraceae, inorganic composition, oleoresin, X-ray fluorescence, Amazonian

\section{Introduction}

Many elements present in the crust of the earth show important functions for living organisms, being essential for their development even in small quantities. Plants absorb part of their inorganic nutrients from the soil, absorbing them through various mechanisms. ${ }^{1}$ Many of these elements can cause disease or intoxication in concentrations just slightly higher than the concentration necessary for a healthy life. Heavy metals, on the other hand, show high toxicity, even at very low concentrations. Some kinds of metals of common use can cause severe processes of

*e-mail: ccsilva@uea.edu.br intoxication, such as chromium. Its accumulation in the organism can lead to the formation of carcinomas. ${ }^{2}$ In excess, copper leads to diseases like Menks Syndrome's and Wilson's disease, both showing cellular degeneration in the human organism. ${ }^{3}$

The presence of metals in medicinal plants must be studied due to the possibility of intoxications from ingesting their extracts, infusions or teas, or even through cutaneous absorption during the healing of wounds. ${ }^{4,5}$ In traditional oriental medicine, like Ayurvedic (Indian) and Chinese medicines, the insertion of heavy metals in the medicinal preparations is very common, bringing on many cases of intoxication by lead, arsenic and mercury. ${ }^{6}$ The determination of metals in plants is not common in Brazil, 
but in a recent study, samples of boldo (Peumus boldus Mol.) from Brazil, Chile, and Argentina were analysed by atomic absorption spectrometry allowing the quantification of iron, manganese, copper and zinc while lead, chromium and cobalt were not detected. ${ }^{7}$

Atomic absorption spectrometry is a quantitative but monoelemental technique, allowing the determination of only one (or a few, in certain instruments) elements at a time. Energy Dispersive X-Ray Fluorescence (EDXRF) using a lithium-silicon detector is a multi-elemental technique in which a unique qualitative analysis provides data about all the elements present with an atomic number between 11 and 92 , that is, between sodium and uranium. ${ }^{8,9}$

Among the natural products of medicinal utilization the oleoresins and, among these, the resins produced by the Burseraceae, one of the most important resin producer families, stand out. This oleoresin is widely utilized in ethnopharmacology for diverse applications, e.g. to heal wounds, as an analgesic and antiseptic. ${ }^{10}$ They are additionally used for cosmetics and perfumes, even being utilized as food in the Amazon Region. ${ }^{11,12}$ Monoterpenoids and triterpenoids were described as the organic compounds of these oleoresins. ${ }^{12}$ Only one paper has recently been published describing the inorganic composition of this family, which concerns stems of Bursera microphylla that was collected in Mexico. Macronutrients such as $\mathrm{Ca}, \mathrm{P}, \mathrm{Mg}$, $\mathrm{Na}$ and $\mathrm{K}$ were described, in addition to the micronutrients $\mathrm{Mn}, \mathrm{Cu}, \mathrm{Fe}$ and $\mathrm{Zn} .{ }^{13}$

In the Negro and Solimões river basins, there is a great endemism of the Burseraceae family, a great variety of minerals in the soil are encountered, including elements that are able to induce to intoxications. Chromium, for example, is described as a component in tourmaline and quartz. Manganese is found in grenades and as a component in staurolites, and zirconium is found in abundance in the Amazonian soil in the zircon $\left(\mathrm{ZrSiO}_{4}\right)$ mineral. ${ }^{14-16}$

In Brazil, there are specific laws that control the presence of metals in commercialized natural products. Bioactive oils and plant extracts commercialized as personal hygiene products, cosmetics and perfumes must be free of $\mathrm{As}, \mathrm{Pb}$, $\mathrm{Cr}, \mathrm{Cd}, \mathrm{Te}, \mathrm{Ta}$, and $\mathrm{Sb}$. In food, there are maximum limits for the following elements: $\mathrm{As}, \mathrm{Pb}, \mathrm{Cd}, \mathrm{Sn}, \mathrm{Cu}$, and $\mathrm{Hg}$. The methodology for analytical quality control that will be applied to detect heavy metals must also be indicated for phytotherapic registration. ${ }^{17}$

Despite the necessity of determination of those metals in phytotherapics, cosmetics, food and perfumes, data about this is rare in the scientific literature. For the products of Amazonian biodiversity, studies that describe the inorganic composition and that are able to orient the methodologies of quality control are even rarer. In an attempt to contribute to the understanding of the inorganic composition of the oleoresins from the Burseraceae family, five Amazonian species had their resins analyzed by EDXRF.

\section{Experimental}

\section{Oleoresins}

Oleoresins from five Burseraceae species were collected in the Reserva Biológica Adolfo Ducke (RBAD), situated at $\mathrm{km} 26$ of the AM-010 highway (030.'00”' $59^{\circ} 52^{\prime} 20^{\prime \prime} \mathrm{W}$ ), Manaus, Brazil: Protium cf. apiculatum (PAP), P. cf. hebetatum (PHB), P. cf. heptaphyllum (PHP), P. tenuifolium (PTE), and Trattinnikia peruviana (TPE). All the samples were collected from only one adult tree from each species (having more than $20 \mathrm{~m}$ in height), on the same day and at a non-flooded "terra firme" rainforest on the plateau region, inside the RBAD.

\section{Oleoresin cleaning and maceration procedures}

Naturally exudated oleoresins were removed from the trunks of trees using a metal spatula, stored at polypropylene plastic bags and kept in a refrigerator until analysis. Oleoresins were manually cleaned of leaves, stems and insects. The oleoresins were then ground in a mortar using a porcelain pestle, reducing them to powder. From a sample of each species more than $10 \mathrm{~g}$ of fine powder were obtained.

\section{Spectroscopic analysis}

The powdered oleoresin was pressed to prepare pastilles: about $2.0 \mathrm{~g}$ from oleoresins were pressed together with $7.0 \mathrm{~g}$ of boric acid $\left(\mathrm{H}_{3} \mathrm{BO}_{3}\right)$.

All analyses were performed utilizing a model EDX700 Energy Dispersive X-Ray Fluorescence (EDXRF) spectrometer, from Shimadzu ${ }^{\odot}$. X-Ray data were obtained utilizing a rhodium tube, with voltage from 0 to $40 \mathrm{KeV}$, collected after $250 \mathrm{~s}$. All elements were identified by their $\mathrm{K} \alpha$ or L $\alpha$ energies and quantification was performed based in cps/uA intensities.

\section{Results and Discussion}

\section{Qualitative aspects}

Various studies report the necessity of some essential chemical elements, like nitrogen and phosphorus, for species of higher economical interest, like soy and corn. One of the reference works in this area was carried out more 
than eight decades ago, in 1924, by Miller. ${ }^{18}$ However, in some of the more modern books on vegetal physiology, the role of mineral and inorganic substances is nor even mentioned. Studies performed with plants of non intensive utilization, like the ones used for medicinal, cosmetic or perfume purposes are ever rarer.

According to vegetal physiology there are nineteen essential chemical elements to the majority of plants. The criteria of essentiality involves three main parts: $(i)$ if the element is removed from the growth medium of a plant, the plant will be unable to complete its vegetative life cycle; (ii) the element is essential if its function is specific and cannot be replaced by other elements; (iii) essentiality is confirmed if the element is a necessary component of an essential metabolite. These elements can be separated into two classes: macroelements (C, H, O, N, P, S, Ca, Mg, Si e K) and microelements ( $\mathrm{Fe}, \mathrm{B}, \mathrm{Mn}, \mathrm{Cl}, \mathrm{Na}, \mathrm{Ni}, \mathrm{Cu}, \mathrm{Zn}$ e Mo). ${ }^{1}$

The number of elements in a plant mainly depends on the elements present in the soil. The amount or proportion of the elements in a plant will vary according to many factors, such as plant species, age, distribution of its roots, the physical and chemical nature of the soil, the proportion and distribution of the elements, methods of cultivation and the general climatic conditions. ${ }^{18}$

The EDXRF analysis of the oleoresin permitted the simultaneous observation of several elements in a fast and quantitative way (Figures 1 and 2). Considering the five species analysed, the elements $\mathrm{S}, \mathrm{Cl}, \mathrm{Ca}, \mathrm{Fe}, \mathrm{Ti}, \mathrm{V}$, and $\mathrm{Si}$, as well as lesser amounts of $\mathrm{Na}, \mathrm{K}, \mathrm{Mg}, \mathrm{Al}, \mathrm{P}, \mathrm{Zr}, \mathrm{Br}, \mathrm{Cr}$, $\mathrm{Cu}$, and $\mathrm{Mn}$ were detected. The first group was observed in all resin samples analyzed. The essential lighter elements, $\mathrm{C}, \mathrm{H}, \mathrm{N}$, and $\mathrm{O}$ are not detected due to limitations in this method so they could not be studied.

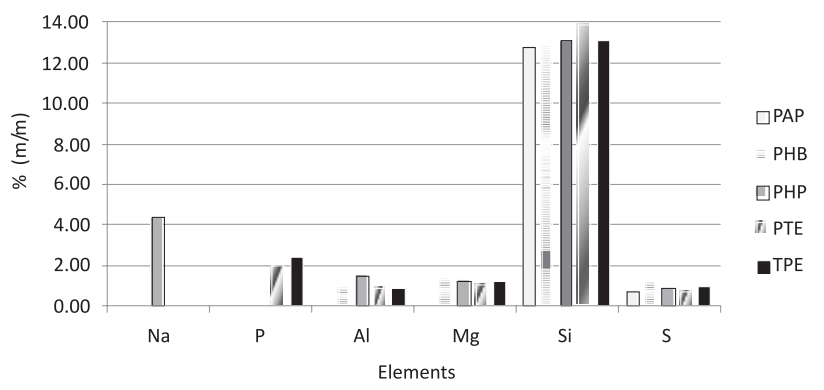

Figure 1. Determination of elements present in higher concentrations.

The essential elements observed in the Burseraceae oleoresins studied are commonly observed in other plants, with variation in the concentrations, depending on the plant species, the region where the sample was collected and the part of the plant studied. ${ }^{4,19}$ The most monitored elements in other plants are the heavy metals, some of them also

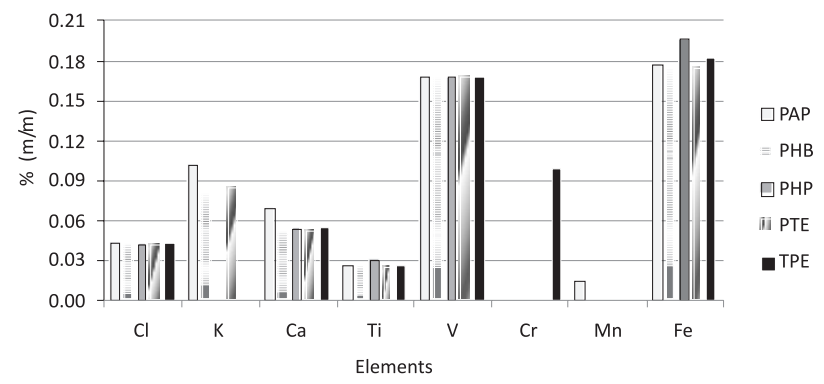

Figure 2. Determination of elements present in lower concentrations.

found in these samples. Among the elements observed in all studied oleoresin samples, both $\mathrm{Ti}$ and $\mathrm{V}$ were detected. Their elevated concentrations in the Amazonian soil suggest that they are replacing other metals found in lower concentrations in this region's soil. Equally rare, $\mathrm{Zr}$, $\mathrm{Cr}$, and $\mathrm{Br}$ were observed. Bromine, however, was only observed in the PHB species, while a Zirconium was detected in two different species: PHP and TPE. Chromium was just found in the TPE species.

Other elements, more common, were also observed only in some of the samples, indicating some selectivity of the species for determined substances. Mn was only found in the PAP species, while $\mathrm{Al}$ and $\mathrm{Mg}$ were absent in this species. $\mathrm{K}$ was not observed in the PHP and TPE samples. Another element found in only one of the species was $\mathrm{Na}$, which was present only in PHP. This could be due to replacing $\mathrm{K}$ in this sample. $\mathrm{P}$ is detected in the PTE and TPE samples.

\section{Quantitative aspects}

Not all the elements were observed in all the samples, but when they were detected, they had similar concentrations. With the exception of aluminum and sulfur (coefficients of variation $30.21 \%$ and $22.39 \%$, respectively), all the elements observed showed coefficients of variation lower than $16 \%$. The concentrations of these elements are presented in Table 1.

The concentration homogeneity of these elements indicates that the oleoresins of this family show characteristic inorganic substances. Inorganic analyses from Burseraceae oleoresins of other regions, with a large number of samples, can confirm if this characteristic composition of the family is related to soil variation or not. In case it is not, a pattern for the Burseraceae oleoresins can be obtained. In the other hand, if variations according to the type of the soil occur, it will be possible to track the oleoresin origins by the inorganic composition, together with organic composition data.

Silicon, found mainly in the tree bark, was one of the elements that was observed in all the samples, with concentrations of $13.11 \%(\mathrm{~m} / \mathrm{m})$, on average. The higher 
Table 1. Concentrations of the elements present in at least two samples $(\%, \mathrm{~m} / \mathrm{m})$

\begin{tabular}{lcccccccccccc}
\hline Sample & $\mathrm{Si}$ & $\mathrm{S}$ & $\mathrm{Cl}$ & $\mathrm{Ca}$ & $\mathrm{Ti}$ & $\mathrm{V}$ & $\mathrm{Fe}$ & $\mathrm{K}$ & $\mathrm{Al}$ & $\mathrm{Mg}$ & $\mathrm{P}$ \\
\hline PAP & 12.79 & 0.72 & 0.04 & 0.07 & 0.03 & 0.17 & 0.18 & 0.11 & - & - & - \\
PHB & 12.77 & 1.18 & 0.04 & 0.05 & 0.03 & 0.17 & 0.17 & 0.08 & 0.89 & 1.29 & - \\
PHP & 13.09 & 0.82 & 0.04 & 0.05 & 0.03 & 0.17 & 0.19 & - & 1.45 & 1.21 & - \\
PTE & 13.84 & 0.69 & 0.04 & 0.05 & 0.03 & 0.17 & 0.18 & 0.08 & 0.85 & 1.03 & 1.93 \\
TPE & 13.06 & 0.91 & 0.04 & 0.05 & 0.03 & 0.17 & 0.18 & - & $0, .81$ & 1.21 & 2.40 \\
Mean & 13.11 & 0.86 & 0.04 & 0.05 & 0.03 & 0.17 & 0.18 & 0.09 & 1.01 & 1.19 & 2.16 \\
Standard Variation & 0.43 & 0.19 & $<0.01$ & 0.01 & 0.0024 & $<0.01$ & 0.01 & 0.01 & 0.30 & 0.11 & 0.33 \\
CV / (\%) & 3.30 & 22.39 & 1.36 & 12.82 & 9.16 & 0.13 & 4.88 & 12.76 & 30.21 & 9.23 & 15.42 \\
\hline
\end{tabular}

percentage was observed for the oleoresin sample of Protium tenuifolium (PTE). Since the oleoresins are exudates from tree bark, its presence can be related to this tissue. $^{18}$

Sulfur is found well distributed through all plant tissues and organs, as a component of a variety of proteins, vitamins and coenzyme A, which takes part in the Krebs cycle. Among the essential elements detected in the samples studied, $\mathrm{S}$ can be found in the highest concentrations, varying from $0.69 \%$ to $1.17 \%(\mathrm{~m} / \mathrm{m})$.

$\mathrm{K}, \mathrm{Mg}, \mathrm{Cl}, \mathrm{Na}$, and $\mathrm{Mn}$ are nutrients found in ionic forms inside the plants, the first three are considered to have more capacity for translocation, but just $\mathrm{Na}$ and $\mathrm{Mg}$ were exudated in significant quantities. Manganese compounds are markedly toxic to plants, except in very low concentrations. ${ }^{1,19,20}$ In similar studies carried out with capim-santo (Cymbopogon citratus Stapf.) and malvariço (Plectranthus amboinicus (Lour.) Spreng.), the concentrations of sodium were similar to those observed in the oleoresins. Even analyzing different parts of the plants we can compare the $\mathrm{Al}, \mathrm{Mg}$ and $\mathrm{K}$ concentrations to ones found in leaves of plants like anador-grande (Justicia gendarussa L.), cidreira (Lippia alba (Mill.) N. E. Brown), and mentrasto (Ageratum conyzoides L.), ${ }^{20}$ consumed by the population as are the oleoresins, where $\mathrm{K}$ concentrations show up near to those found in these species, the same occurring for $\mathrm{Al}$ and $\mathrm{Mg}$, with small variations.

$\mathrm{Fe}$ and $\mathrm{Cu}$ were studied for leaves of other medicinal plants like aroeira-da-praia (Schinus terebinthifolius Raddi.) and artemisia (Artemisia vulgaris L.), ${ }^{4}$ and their quantities are compatible to the ones found here. They are nutrients involved in redox reactions in plants and are considered with low capacity for translocation, such as the Ca fixed in cellular walls. ${ }^{21}$ Even so, these elements were detected in low quantities in these samples.

Some elements like $\mathrm{Cr}$, have a dual behavior, essentiality and toxicity, for both plants and human beings, according to the valence state. In its toxic form, $\mathrm{Cr}$ can generate carcinomas. $^{2,18}$ The TPE sample shows $0.09 \%(\mathrm{~m} / \mathrm{m})$ of total Cr. As defined by Brazilian law (RDC 48/2006), chromium should not be present in cosmetics; thus, the presence of this metal should be monitored.

$\mathrm{Cu}$ and $\mathrm{Zr}$ were observed in very low concentrations, under the limit of quantification of the equipment. $\mathrm{Br}$ was also detected at very low levels. Thus, there are not significant possibilities of intoxications by these elements.

\section{Conclusions}

The analyses of elemental chemical composition showed metals considered harmful to human health, like chromium, manganese, bromine and copper. These metals, depending on the quantity absorbed by humans, can cause diseases related to their accumulation in the organism, demonstrating that there is a need to be cautious on applying the oleoresin in folk medicine and as a phytotherapic. The presence of chromium in the samples suggests the necessity of its quantification when the Burseraceae resins are utilized in cosmetics, perfumes and personal hygiene products, as is very common in Brazil.

The elements present in the oleoresins were observed as having different profiles for each species. These can be utilized as potential markers between the species groups, with a specificity being observed between some elements and some species, like chromium, manganese, bromine and sodium. Among the elements found in all the samples, it is clear that there is no great variation in the absorption by each species. Having this information we can demonstrate that this method is adequate and confirms presence of these elements for these species in similar quantities.

The presence of non-metals in the oleoresin was observed in the analyses. Those substances could be present as inorganic salts, organochloride or sulfate compounds. Selective isolation should be performed to evaluate in which form these elements are present. The results suggest the possibility that the utilization of some elements in systematic analysis can be possible. Analysis 
of other oleoresins will be necessary, in combination with soil analysis from where they were collected as well as determinations of other parts of plants in order to reach better conclusions.

\section{Acknowledgments}

The authors acknowledge to CNPq and FAPEAM for financial support. One of the authors (A.L.R.) acknowledges a research grants received from CAPES.

\section{References}

1. Taiz, L.; Zeiger, E.; Fisiologia Vegetal, $3^{\text {rd }}$ ed., Bookman: São Paulo, Brasil, 2004, ch. 5.

2. Ferreira, A. D. Q.; Quim. Nova 2002, 25, 572.

3. Milne, D. B. In Fundamentos de Química Clínica; Burtis, C. A.; Ashwood, E. R., eds.; $4^{\text {th }}$ ed., Guanabara Koogan: Rio de Janeiro, Brasil, 1970, ch. 27.

4. Lopes, M. F. G.; Almeida, M. M. B.; Nogueira, C. M. D.; Magalhães, C. E. C.; Morais, N. M. T.; Rev. Bras. Farmacogn. 2002, 12, 115 .

5. Gomes, M. R.; Soledad, C.; Olsina, R. A.; Silva, M.; Martinez, L. D.; J. Pharm. Biomed. Anal. 2004, 34, 569.

6. Veiga Junior, V. F.; Pinto, A. C.; Maciel, M. A. M.; Quim. Nova 2005, 28, 519.

7. Schwanz, M.; Ferreira, J. J.; Fröehlich, P.; Zuanazzi, J. A. S.; Henriques, A. T.; Braz. J. Pharmacog. 2007, 18, 98.

8. Leyden, D. E.; Fundamentals of X-Ray Spectrometry as Applied to Energy-Dispersive Thecniques, Tracor X-Ray, Mountain View: California, 1984.
9. Butin, E. P.; Principles and Pratice of X-Ray Spectrometric Analisis, Plenum Publishing Corporation: New York, 1970.

10. Pio Correa, M.; Dicionários de Plantas Úteis do Brasil e das Exóticas Cultivadas, Ministério da Agricultura: Brasília, Brasil, 1984.

11. Pernet, R.; J. Nat. Prod. 1972, 35, 280.

12. Rüdiger, A. L.; Siani, A. C.; Veiga Junior, V. F.; Pharmacogn. Rev. 2007, 1, 93.

13. Ramírez-Orduña, R.; Ramirez, R. G.; González-Rodríguez, H.; Haenlein, G. F. W.; Small Ruminant Res. 2005, 57, 1.

14. Landim, P. M. B.; Nivaldo, J. B.; Wu, F. T.; Castro, P. R. M.; Acta Amaz. 1983, 13, 51.

15. Horbe, A. M. C.; Paiva, M. R. P.; Motta, M. B.; Horbe, M. A.; Acta Amaz. 2007, 37, 81.

16. Küchler, I. L.; Miekeley, N.; Forsberg, B. R.; J. Braz. Chem. Soc. 2000, 11, 286.

17. RDC 48 (16-3-2004); Portaria 685 (27-8-1998); RDC 48 (16-32006), in http://www.anvisa.gov.br/e-legis, accessed in January 2009.

18. Miller, E.; Plant Physiology, $2^{\text {nd }}$ ed., McGraw-Hill Book Company, Inc.: New York, 1938, ch. 6.

19. Almeida, M. M. B.; Lopes, M. F. G.; Nogueira, C. M. D.; Magalhães, C. E. C.; Morais, N. M. T.; Ciênc. Tecnol. Aliment. 2002, 22, 94 .

20. Meyer, B.; Anderson, D.; Bohning, R.; Fratianne, D.; Introdução à Fisiologia Vegetal, $2^{\text {nd }}$ ed., Atlantida Editora: Coimbra, Portugal, 1983, ch. 15.

21. Salisbury, F. B.; Ross, C. W.; Plant Physiology, $4^{\text {th }}$ ed., Wadsworth Publishing Co., Belmont, California, 1992, ch. 6.

Received: February 3, 2009 Web Release Date: June 18, 2009 